\section{Anterior spinal artery supplying posterior circulation}

J.S. Hott, MD, G. Vishteh, MD, R. Wallace, MD, B.L. Dean, MD, and R.F. Spetzler, MD, Phoenix, $A Z$

CT showed diffuse intraventricular hemorrhage in a 68-yearold man involved in a motor vehicle accident. MR angiography showed superiorly directed flow in the anterior spinal artery (ASA) supplying the basilar artery and posterior circulation (figure 1). MR angiography demonstrates flow only in the cephalad direction because inferiorly directed flow has been selectively saturated out. Conventional angiography confirmed the flow reversal (figure 2).

Under normal conditions, blood in the ASA flows inferiorly. An artery to the cervical cord often arises from the vertebral artery (VA). ${ }^{1,2}$ In this case, a C4 segmental artery supplies the ASA, which fills retrograde (cephalad direction) to the vertebrobasilar junction providing collateral supply to the posterior circulation. The demand created by VA occlusions and lack of collateral circulation through the posterior communicating arteries caused the flow reversal in the ASA.

1. Asai J, Hayashi T, Suzuki R, Fujimoto T, Nagashima G. Spontaneous resolution of an idiopathic cervical direct vertebral arteriovenous fistula after partial coil embolization in a patient presenting with myeloradiculopathy. Clin Neurol Neurosurg 2002;104:146-151.

2. Lee TT, Gromelski EB, Bowen BC, Green BA. Diagnostic and surgical management of spinal dural arteriovenous fistulas. Neurosurgery 1998; 43:242-247.

Address correspondence and reprint requests to Dr. Robert F. Spetzler, c/o Neuroscience Publications, Barrow Neurological Institute, 350 West Thoma Road, Phoenix, AZ 85013-4496; e-mail: neuropub@chw.edu

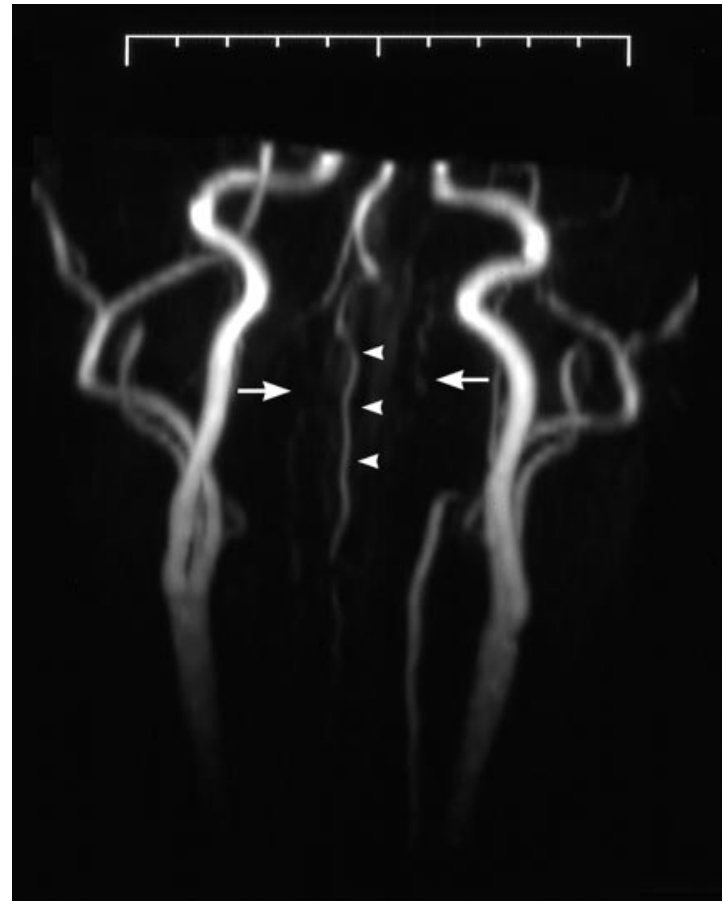

Figure 1. MRA (two-dimensional time of flight) shows cephalad flow in the anterior spinal artery (arrowheads) supplying basilar artery and none in right vertebral artery (VA). Flow only in the proximal left VA suggests distal stenosis or occlusion (arrows).
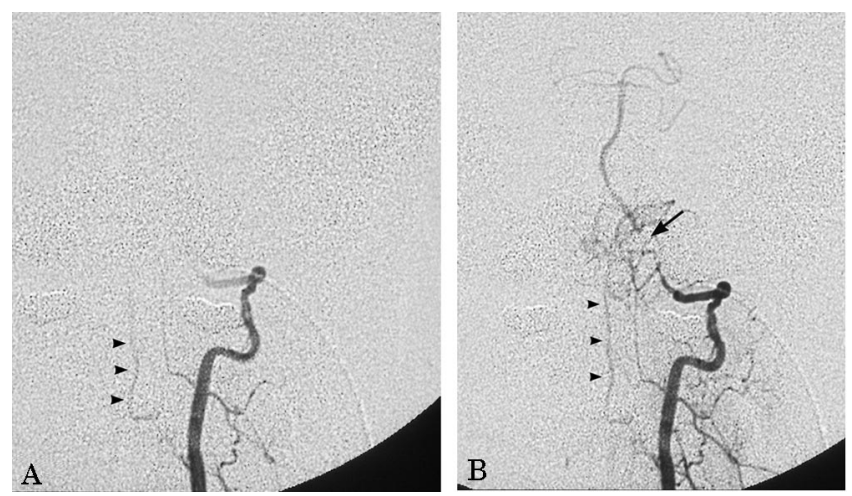

Figure 2. (A) Early and (B) later phase angiograms show shortsegment occlusion (arrow) of left distal vertebral artery, and superior flow in anterior spinal artery (arrowheads) supplying the posterior circulation. 


\section{Neurology}

\section{Anterior spinal artery supplying posterior circulation}

J. S. Hott, G. Vishteh, R. Wallace, et al.

Neurology 2004;62;468

DOI 10.1212/01.WNL.0000106825.66718.E4

\section{This information is current as of February 9, 2004}

\section{Updated Information \& Services}

References

Citations

Subspecialty Collections

Permissions \& Licensing

Reprints including high resolution figures, can be found at: http://n.neurology.org/content/62/3/468.full

This article cites 2 articles, 0 of which you can access for free at: http://n.neurology.org/content/62/3/468.full\#ref-list-1

This article has been cited by 1 HighWire-hosted articles: http://n.neurology.org/content/62/3/468.full\#\#otherarticles

This article, along with others on similar topics, appears in the following collection(s):

\section{All Imaging}

http://n.neurology.org/cgi/collection/all_imaging

All Spinal Cord

http://n.neurology.org/cgi/collection/all_spinal_cord

MRI

http://n.neurology.org/cgi/collection/mri

Information about reproducing this article in parts (figures,tables) or in its entirety can be found online at:

http://www.neurology.org/about/about_the_journal\#permissions

Information about ordering reprints can be found online: http://n.neurology.org/subscribers/advertise

Neurology $®$ is the official journal of the American Academy of Neurology. Published continuously since 1951, it is now a weekly with 48 issues per year. Copyright . All rights reserved. Print ISSN: 0028-3878. Online ISSN: 1526-632X.

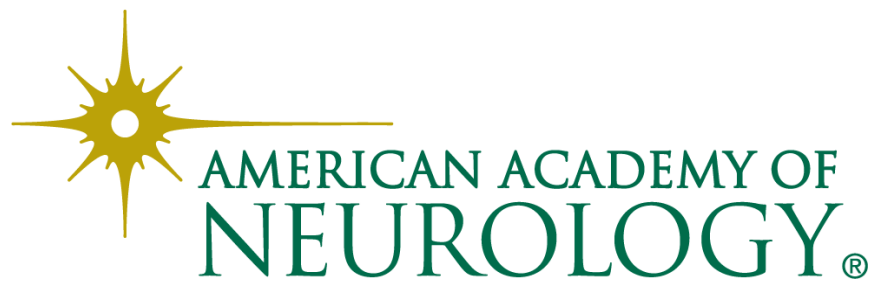

